University of Denver

Digital Commons @ DU

Sturm College of Law: Faculty Scholarship

University of Denver Sturm College of Law

2016

Marijuana Legalization in Colorado: Lessons for Colombia

Sam Kamin

Follow this and additional works at: https://digitalcommons.du.edu/law_facpub

Part of the Law Commons

Recommended Citation

Journal Colombian Institute of Tax Law No. 75 (2016).

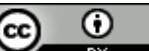

This work is licensed under a Creative Commons Attribution 4.0 License.

This Paper is brought to you for free and open access by the University of Denver Sturm College of Law at Digital Commons @ DU. It has been accepted for inclusion in Sturm College of Law: Faculty Scholarship by an authorized administrator of Digital Commons @ DU. For more information, please contact jennifer.cox@du.edu,digcommons@du.edu. 


\section{Marijuana Legalization in Colorado: Lessons for Colombia}

\section{Publication Statement}

Copyright held by the author. User is responsible for all copyright compliance. 


\title{
Marijuana Legalization in Colorado - Lessons for Colombia
}

\author{
Legalización de la marihuana en Colorado \\ - Lecciones para Colombia
}

\author{
Legalização da maconha no Colorado \\ - Lições para a Colômbia
}

\begin{abstract}
SAM KAMIN ${ }^{1}$
Vicente Sederberg Professor of Marijuana Law and Policy, University of Denver Sturm

College of Law - Denver, Colorado, Estados Unidos de América
\end{abstract}

Página inicial: 339

Página final: 356

\begin{abstract}
In 2012 Colorado became the first jurisdiction anywhere in the world to legalize marijuana possession and use for all adults. The regulated and taxed marijuana industry that arose in Colorado following legalization was also the first of its kind and stands as a model for other states considering marijuana law reform. In this brief article I discuss the results of the Colorado experiment. I demonstrate that while Colorado's regulatory model was largely successful, it also demonstrates the limits of generating revenue through taxing and regulating marijuana. I then discuss the implications of this conclusion for post-conflict Colombia, drawing a
\end{abstract}

1 Sam Kamin joined the faculty at the Sturm College of Law in 1999 and is currently the Vicente Sederberg Professor of Marijuana Law and Policy. Holding both a J.D. and a Ph.D. from the University of California at Berkeley as well as a BA, summa cum laude, from Amherst College, Professor Kamin's research interests include criminal procedure, death penalty jurisprudence, federal courts, and constitutional remedies. He is a co-author of West Publishing's Investigative Criminal Procedure: A Contemporary Approach and Cases and Materials on the Death Penalty and has published scholarly articles in the Virginia Law Review, the Indiana Law Journal, the Journal of Constitutional Law, and Law and Contemporary Problems among many others.

I would like to thank the organizers of the Colombian Institute of Tax Law for the invitation to participate in this Congress and to contribute to this collection.

* $\quad$ Este artículo puede citarse de la siguiente forma: Sam Kamin. Marijuana Legalization in Colorado - Lessons for Colombia. Revista Instituto Colombiano de Derecho Tributario, núm. 75. Noviembre 2016. At. 339. 
comparison to the situation California confronts as it considers legalizing marijuana for adult use.

\section{Keywords}

Marijuana regulation, Drug policy, Law reform, Federalism, Post-conflict, Colombia, Colorado.

\section{Resumen}

En el 2012 Colorado fue la primera jurisdicción en todo el mundo en legalizar la posesión y el uso de la marihuana en los adultos. La regulación e imposición tributaria sobre la industria creció en Colorado después de la legalización; esta también paso a ser la primera de su tipo y estableció un modelo para otros Estados interesados en establecer una reforma de ley de marihuana. En este breve artículo se discutirá los resultados de la experiencia en Colorado. Al demostrar que el modelo de regulación de Colorado es todo un éxito, también se evidenciarán los límites en la generación de ingresos a través de los impuestos y la regulación de la marihuana. Luego se discutirán las implicaciones de esta conclusión en el posconflicto de Colombia, por intermedio de la comparación de la situación de California y su dilema en la consideración en la legalización del uso de marihuana por adultos.

\section{Palabras clave}

Regulación de la marihuana, Política de estupefacientes, Reforma de ley, Federalismo, Posconflicto, Colombia, Colorado.

\section{Resumo}

No 2012 o Colorado foi a primeira jurisdição no mundo todo em legalizar a possessão e o uso da maconha nos adultos. A regulação e imposição tributária sobre a indústria cresceu no Colorado depois da legalização; tal, também passou a ser a primeira de seu tipo e estabeleceu um modelo para outros estados interessados em estabelecer uma reforma de lei de maconha. Neste breve artigo se discutirá os resultados da experiência no Colorado. Ao demonstrar que o modelo de regulação do Colorado é um grande sucesso, também se evidenciaram os limites na geração de ingressos através dos impostos e a regulação da maconha. Depois se discutirá as implicações desta conclusão no pós-conflito da Colômbia, por intermeio da comparação da situação da Califórnia e o seu dilema na consideração na legalização do uso da maconha por adultos. 


\section{Palavras-chave}

Regulação da maconha, Política de estupefacientes, Reforma de lei, Federalismo, Pós-conflito, Colômbia, Colorado.

\section{Summary}

Introduction; 1. Marijuana Policy in the United States Today; 2. The Colorado Model of Marijuana Regulation, 2.1. Designing the Market; 3. Taxation; 4. Results; 5. California and the Colombia Example; 6 . Conclusion.

\section{Introduction}

In 2012 Colorado, along with Washington State, became the first jurisdiction on earth to legalize, tax and regulate marijuana for all adult users. In November of that year, Colorado voters passed Amendment 64 by a vote of $55 \%$ to $45 \%{ }^{2}$; the measure immediately legalized possession of less than an ounce of the drug by adults $^{3}$ and authorized citizens to grow up to six plants per person at home ${ }^{4}$. It also called upon the state legislature to pass regulations to license and tax the commercial production and sale of the drug by January $1,2014 .{ }^{5}$

Amendment 64 was tellingly subtitled: A Bill to Regulate Marijuana like Alcohol $^{6}$. The measure's explicit pitch to voters was that marijuana should be treated not as something to be prohibited and punished criminally, but rather as a substance that adult users should be able to choose to enjoy in the context of a regulated - and perhaps more importantly, taxed - marketplace ${ }^{7}$. Proponents of marijuana legalization in the states often pitch a regulated adult use regime for marijuana as offering a double financial boon to a state's economy - a state choosing to legalize marijuana can spend less money on law enforcement while capturing for itself revenue that is currently being monopolized by criminal gangs importing and se-

2 See, Amendment 64, Election Results, available at:http://data.denverpost.com/election/results/ amendment/2012/64-legalize-marijuana/.

Co. Const. Art. XVII Sec. 3(a).

Co. Const. Art. XVII Sec. 3(b).

Co. Const. Art. XVII Sec. 5.

Co. Const. Art. XVII Sec. 1(a). ("In the interest of the efficient use of law enforcement resources, enhancing revenue for public purposes, and individual freedom, the people of the state of Colorado find and declare that the use of marijuana should be legal for persons twenty-one years of age or older and taxed in a manner similar to alcohol".)

7 See, e.g., The Campaign to Regulate Marijuana like Alcohol, available at: http://www.regulatemarijuana. org/about ("Regulating marijuana like alcohol will take marijuana sales out of the hands of cartels and criminals, and redirect that money toward legitimate, taxpaying Colorado businesses".). 
lling the drug ${ }^{8}$. This combination - more revenue, fewer expenditures -can prove a powerful argument with voters during difficult financial times.

More than a year after adult-use (or "recreational") marijuana sales were begun in Colorado, I was asked to speak to the ICDT on the revenue potential and impact of moving from drug prohibition to regulation and taxation and on the implications of the Colorado experiment for post-conflict Colombia. Briefly summarized, my conclusions are these: It is easy to overestimate both the revenue that can be generated by taxing the sale of marijuana and the cost savings associated with legalization. In other words, although there may be very good reasons for moving away from marijuana prohibition - the impact it has on communities of color, the wasted lives and resources associated with criminalizing possession crimes, the incentives prohibition creates for violent criminal gangs to flourish - financial windfall should probably not be one of them. I then analogize the situation in post-conflict Colombia with the legalization quandary facing California - how to incorporate into a taxed and regulated marketplace a group of producers who have been operating outside the law for many years.

\section{Marijuana Policy in the United States Today}

Marijuana remains prohibited under federal law in the United States. It is a Schedule I drug under the federal Controlled Substances Act (CSA) ${ }^{9}$. Thus, since 1970 when the CSA was passed, the production, distribution, and possession of marijuana have all been serious felonies, punishable by up to life imprisonment ${ }^{10}$. While the states originally passed their own provisions criminalizing marijuana ${ }^{11}$, and often worked closely with the federal government to implement marijuana prohibition, in recent years they have increasingly judged marijuana's continued criminality more skeptically. In 1996, California passed Proposition 215, becoming the first state to legalize marijuana for medical purposes. ${ }^{12}$

8 See, e.g., Why We Need to Finally Legalize Marijuana, Daily Dot, available at: http://www.dailydot.com/ opinion/marijuana-legalization-economic-argument/ ("legalization would provide top-down economic improvements in local communities, state coffers, and more. In addition to bringing in funds, it would save regional and state governments substantial sums in currently wasted law enforcement dollars".).

921 U.S.C. Sec. 812(c)(17).

1021 U.S.C. Sec. 841(b)(1)(vii)(imposing a sentence of "not less than 10 years or more than life" if the defendant is convicted of an offense involving " 1,000 kilograms or more of a mixture or substance containing a detectable amount of marihuana, or 1,000 or more marijuana plants regardless of weight”.).

11 In 1986, Oregon became the first state to de-criminalize marijuana possession. See, David Lamb, Other Emotional Issues on Ballots Nationwide: Five States Are Apparently Ready to Adopt Lotteries. L.A. TIMES. November 5, 1986. Http://articles.latimes.com/1986-11-05/news/mn-15354_1_lottery-initiative.

12 State Marijuana Laws. National Conference of State Legislatures. August 20, 2015. ("In 1996, California voters passed Proposition 215, making the Golden State the first in the union to allow for the medical use of marijuana".). 
Although, as will be discussed more fully below, the California law was hardly a model of effective regulation and public policy, California's choice to permit the medical use of marijuana quickly caught on in other states that had grown weary of treating marijuana as a criminal problem. Over the next twenty years, 22 of the 50 states and the District of Columbia followed suit, passing medical use laws like California's, often by means of direct initiative rather than legislative enactment. These state provisions generally exempt patients and their care-giver sand providers from state criminal laws if the patient can demonstrate a medical need for the drug. Doctors still cannot prescribe marijuana under state medical marijuana laws - it remains a prohibited substance under federal law and any doctor who writes a prescription for it risks losing his license - but are able to make less formal "recommendations" to their patients. Some states explicitly authorized commercial dispensaries to sell medical marijuana to patients with a doctor's recommendation while others were silent on the matter of how marijuana was to be obtained; some states heavily regulated their medical marijuana markets while others, like California, left regulation largely to local governments, resulting in a patchwork of unpredictable and often confusing regulations. ${ }^{13}$

Medical marijuana laws in the states were met with a mixed reaction; some saw them as a charade and a mere stepping stone to full legalization ${ }^{14}$. There was a belief that medical marijuana was in many ways a sham and that healthy young people were using the cover of medical necessity to cloak their recreational use ${ }^{15}$. By contrast, others felt the laws did not go far enough and pushed for full legalization of marijuana in the states. When California considered, but ultimately rejected full legalization of marijuana for all adults in 2010, some of the principal arguments made for moving beyond medical marijuana included eliminating the cost of the

13 Pathways Report: Policy Options for Regulating Marijuana in California, Blue Ribbon Commission on Marijuana Policy. Hereinafter, BRC Report. At 10. ("California is home to the nation's oldest medical marijuana industry. Voters passed Proposition 215 in 1996, making it the first state to legalize cannabis use for medicinal purposes. This industry includes entities involved in cultivation, retail sales, testing and many other functions. While the industry is 20 years old, it is largely unregulated at the state level").

14 See, e.g., Michael Roberts, Medical Marijuana v. Recreational Use: NORML Controversy, Colorado Connection, Westword (January 15, 2012) available at: http://www.westword.com/news/medical-marijuanav-recreational-use-norml-controversy-colorado-connection-5897167 (Quoting NORML president Alan St. Pierre as describing "medical marijuana as a 'sham' on par with prescription alcohol during the 1920s liquor-prohibition era”.).

15 See, e.g., Tom Keane. The "Medical Marijuana" Sham. Boston Globe. August 5, 2012, Https:// www.bostonglobe.com/opinion/2012/08/04/medical-marijuana-just-backdoor-way-legalizingweed/3fLD096MPkfzpg8KHatv9I/story.html ("[M]uch of the medical marijuana movement is just a backdoor attempt at legalization. I understand the push to medicalize pot. If the United States were still under Prohibition, I imagine we'd see a clamor to get doctors to prescribe red wine for people's hearts — and undoubtedly a large proportion of the population would sign up. But that charade would make a mockery of the law, and so does medical marijuana. If it's really medicine, then let the FDA test and approve it. If the real goal is legalization, then do so openly: regulate it, tax it, and get crooks out of the business of growing and distributing it".). 
marijuana drug war ${ }^{16}$ and the disparate impact that marijuana prohibition has on certain racial and ethnic groups. ${ }^{17}$

Despite the failure of California's adult use initiative just two years earlier, in 2012 Colorado and Washington became the first states to go beyond permitting medical marijuana, legalizing marijuana use for all adults 21 and over and calling on lawmakers to create a tax and regulatory apparatus for retail marijuana sales. In 2014, with retail sales now underway in both Colorado and Washington, the states of Alaska, Oregon, and the District of Columbia followed suit, raising the number of adult use jurisdictions to five. A number of states will be considering adult use laws in 2016, including California, the nation's largest state and the first to have adopted medical marijuana laws. The momentum for marijuana change in the United States is only accelerating and appears to be reaching a tipping point - as more and more states legalize marijuana, the status quo in which the drug is legal in a majority of states while still prohibited at the federal level becomes untenable. ${ }^{18}$ With the swearing in of a new president in 2017, hopes are high among marijuana reform groups that there will be a fundamental change of policy at the federal level.

Absent such a change, though, things remain uncertain at the moment, even as the states scramble to rethink their marijuana prohibitions. To grasp the legal meaning of marijuana law reform in the states, it is important to understand the distribution of power between the state and federal governments in the American system. Although they may choose to do so, the federal government cannot force the states to pass laws analogous to the Controlled Substances Act, to enforce the states' own drug laws, or to help the federal government enforce the CSA; the anti-commandeering principle of the Tenth Amendment to the Constitution prevents the federal government from making the states the unwilling instruments of federal policy. ${ }^{19} \mathrm{But}$ the federal government is hardly toothless in this regard, for federal

16 See, California Voter Guide, Proposition 19 (2010), available at: http://www.voterguide.sos.ca.gov/ past/2010/general/propositions/19/arguments-rebuttals.htm ("Today, hundreds of millions of taxpayer dollars are spent enforcing the failed prohibition of marijuana .... Police waste millions of taxpayer dollars targeting non-violent marijuana consumers, while thousands of violent crimes go unsolved".).

17 See, e.g., Wyatt Buchanan. California NAACP Backs California Ballot Measure. Los Angeles Times. June 30, 2010 ("The California NAACP has endorsed a November ballot measure to legalize adult recreational use of marijuana, calling the measure a civil rights issue because blacks have a disproportionate number of arrests for marijuana possession compared with whites. Accompanied by other African American leaders in California, the president of the state NAACP, Alice Huffman, said the current prohibition on marijuana has led to the criminalizing of young people and consequently has hampered the ability of many African Americans to prosper".).

18 See, e.g., Erwin Chemerinsky, Jolene Forman, Allen Hopper et al., Cooperative Federalism and Marijuana Regulation. 62UCLA L. Rev. 74, 90-100. 2015 (listing the banking, taxation, and personal liberty implications of marijuana's continuing federal prohibition).

19 New York v. United States, 505 U.S. 144, 175 (1992) (holding that allowing Congress to impose obligations on the state legislature "would 'commandeer' state governments into the service of federal regulatory purposes, and would for this reason be inconsistent with the Constitution's division of authority between 
law remains supreme in the American system. This means that so long as marijuana remains illegal under federal law the federal government retains he power to arrest and prosecute anyone, at any time, in any state, who is in violation of federal law ${ }^{20}$. While the federal government obviously lacks the resources to arrest everyone involved in the production and sale of marijuana in an enormous state like California or even a medium-sized one like Colorado ${ }^{21}$, it needs not do so in order to cripple the industry and bring marijuana law reform to a halt. Once it is clear that everyone involved in the industry is subject to the risk of losing their livelihood and the possibility of long sentences of imprisonment, an already financially tenuous industry will likely unravel.

So it was a relief for many in the industry - and in state government in those states seeking to implement legalization - when the federal government announced in the fall of 2013 that it would allow the state experiments with legalization to proceed without federal interference ${ }^{22}$. The federal government's green light to the states was not without conditions, however. Instead, the federal government stated that it would be monitoring the progress of marijuana regulation in the states and reserving its rights to intervene if necessary. In doing so the Obama administration set forth eight criteria it would use to evaluate the states in order to assure that their regulatory regimes were robust, not just on paper but in practice as well.

The Department in recent years has focused its efforts on certain enforcement priorities that are particularly important to the federal government:

1) Preventing the distribution of marijuana to minors;

2) Preventing revenue from the sale of marijuana from going to criminal enterprises, gangs, and cartels;

3) Preventing the diversion of marijuana from states where it is legal under state law in some form to other states;

4) Preventing state authorized marijuana activity from being used as a cover or pretext for the trafficking of other illegal drugs or other illegal activity;

federal and state governments".); Printz v. United States, 521 U.S. 898, 933 (1997) (citing New York for the proposition that state law enforcement officials cannot be forced to implement federal programs).

20 United States v. Oakland Cannabis Buyers' Coop. 523 U.S. 483 (2001) (rejecting a medical necessity defense in a federal prosecution under the Controlled Substances Act).

21 See, Chemerinsky, et al. At. 84 ("Since the CSA's implementation more than forty years ago, nearly all marijuana enforcement in the United States has taken place at the state level. For example, of the nearly 900,000 marijuana arrests in 2012, arrests made at the state and local level dwarfed those made by federal officials by a ratio of 109 to $1 ")$.

22 James M. Cole. Memorandum for All United States Attorneys: Guidance Regarding Marijuana Enforcement. August 29, 2013. 
5) Preventing violence and the use of firearms in the cultivation and distribution of marijuana;

6) Preventing drugged driving and the exacerbation of other adverse public health consequences associated with marijuana use;

7) Preventing the growing of marijuana on public lands and the attendant public safety and environmental dangers posed by marijuana production on public lands; and

8) Preventing marijuana possession or use on federal property. ${ }^{23}$

As we shall see, these priorities, and the states' desire to comply with them, color nearly all policy decisions being made in this field.

\section{The Colorado Model of Marijuana Regulation}

\subsection{Designing the Market}

Although Colorado and Washington began their adult use experiments at the same time, Colorado's regulatory regime is more advanced than Washington State's ${ }^{24}$ and is a better place to begin our analysis. Colorado is a mid-sized state located in the middle of the United States, both geographically and politically in recent elections it has been one of a handful of hotly contested states and is seen as a national bellwether ${ }^{25}$. Politics in Colorado - unlike in more left-leaning states like Washington - tend to be more libertarian than liberal. Marijuana legalization passed in Colorado in large part because of a left-right coalition in favor of it - those on the left saw it as a civil liberties and social justice issue; those on the right were motivated by concerns about the reach of the federal government.

The regulatory regime that arose in Colorado in 2013 - after the passage of Amendment 64 and before the opening of retail marijuana establishments the following year - stands in many ways as model for other states considering marijuana legalization. Following the passage of Amendment 64, Colorado's Governor appointed a Task Force to help implement the will of the voters and to make

23 Id. at $1-2$

24 Trevor Hughes. Marijuana Legal, But Often Scarce in Washington State. USA Today. September 26, 2014. Http://www.usatoday.com/story/news/nation/2014/09/26/washington-marijuana-legal-scarce/16266573/ ("A little more than two months after Washington launched recreational marijuana sales, you'd be hard pressed to stumble upon any pot shops in the state's biggest city: Until this weekend, only one marijuana store was open in Seattle, and getting there required a trek through industrial developments far from downtown. And when you reach the store, you might not find any pot on the shelves".).

25 See, e.g., Frank Bruni. A Battleground and a Bellwether. New York Times. August 16, 2014 (writing that "[S] eemingly every big issue finds vivid expression here, and that Colorado has become the nation's mirror, rocky and stoned".). 
suggestions to the legislature regarding how to regulate adult-use marijuana ${ }^{26}$. The Task Force, drawing on Colorado's existing medical marijuana rules, ended up making fifty eight recommendations which eventually formed the basis of the state's first-in-the-world recreational marijuana regulations ${ }^{27}$. If one imagines a continuum from full marijuana prohibition to full marijuana legalization, Colorado's approach is certainly at the more permissive end ${ }^{28}$. Colorado adopted a marketbased approach, licensing and taxing private, commercial producers and retailers of marijuana as well as manufacturers of infused marijuana products. Although a number of conditions are placed on the obtaining of a license ${ }^{29}$, there is not a limit on either the number of licenses that can be issued or the total amount of marijuana and marijuana-infused products that can be produced in the state; rather it is left to supply and demand to determine how much marijuana the market can bear. By contrast, other states have sought to limit supply by limiting either the number of licenses or the total amount of marijuana that can be produced in the state ${ }^{30}$. In other words, Colorado opted for an open but regulated marketplace.

The centerpiece of marijuana regulation in the state is seed to sale surveillance of growing and retail operations. To keep legally-produced marijuana from flowing to the black market - and to avoid a federal crackdown on the industry Colorado established a rigorous system of surveillance and inspection of licensed entities. Video recording is required in every sensitive area of a licensed entity ${ }^{31}$; only badged and licensed employees are allowed into those areas where marijuana is processed or sold ${ }^{32}$. In addition, each plant is tagged when it produces its first roots - yellow tags for plants in the medical market, blue for plants in the recreational market ${ }^{33}$. Each tag contains a radio frequency chip that stays with the plant from seedling, through growth and flowering, to drying, curing, and packaging for

26 See, e.g., Brady Dennis. Colorado Starts to Plot Course for Legal Pot. Washington Post. December 14, 2012.Http://www.washingtonpost.com/national/health-science/colorado-starts-to-plot-course-for-legalpot/2012/12/14/b294f11a-447f-11e2-8061-253bccfc7532_story.html. I was honored to be asked to serve on the Task Force as a legal expert.

27 Task Force Report on the Implementation of Amendment 64. Hereinafter Task Force Report. March 12 , 2013.

28 See, e.g., Jonathan P. Caulkins, Beau Kilmer, Mark A. R. Kleiman, et al. Considering Marijuana Legalization: Insights for Vermont and Other Jurisdictions.

29 Licensees must be Colorado residents with clean criminal histories.

30 See Valerie Bauman. Washington Limits How Much Marijuana Can Be Grown in the State. Puget Sound Business Journal. February 19, 2014. A state-run model like the one adopted by Uruguay is not an option in the United States. Because marijuana remains illegal at the federal level, a state that was in the business of producing marijuana itself would raise serious federalism concerns - it is one thing for a state to permit its citizens to cultivate and sell marijuana in violation of federal law; it is something else altogether for a state to be directly involved in that violation. See, e.g., Chemerinsky, et al. At 106 ("[l]f a state were to make state officers the manufacturers or distributors of marijuana, it might well be impossible for those officials to comply with both state and federal law".).

31 1CCRR306.

32 1CCRR233.

33 1CCRR309D. 
sale; agents of the Department of Revenue are able to scan a facility to determine how many plants are present and whether they are all accounted for. Records are kept of the plant's weight at each stage of the process, and the licensed business is obligated to account for every ounce that is produced and sold. ${ }^{34}$

Needless to say, this system is expensive. From the point of view of the regulated business, there are large upfront costs - paying licensing fees to the state, purchasing the RF tags, the video cameras, the computers that store the video images, the inventory system, and so forth. - as well as the ongoing costs of training employees to comply with the system. But from the point of view of the regulator, the costs are significant as well. For if a regulatory regime is to be robust in practice and not just on paper - as federal law demands that it be - there will be substantial costs associated with it. The Department of Revenue must employ agents to investigate the backgrounds of applicants for licenses, to conduct compliance investigations in the field, and to bring enforcement actions against those it deems to be out of compliance.

But, and this is the truly important point, these administrative costs have not replaced law enforcement costs; they have merely added to them, for to say that marijuana is legal in Colorado is not to say that it is completely legal. In fact, Colorado has merely carved a few small exceptions to its otherwise intact marijuana prohibition. It is still illegal, for example, to grow more than a small number of plants without a license, to sell any amount of marijuana without a license, to manufacture marijuana-infused products without a license, or for anyone, whether licensed or not, to distribute marijuana to minors or outside the boundaries of the State of Colorado. While the number of marijuana arrests naturally dropped shortly after Amendment 64 passed ${ }^{35}$ and was implemented -much, but not all, of the conduct previously punished criminally is no longer against the law - investigation of serious criminal marijuana activity remains a priority for Colorado law enforcement officials.

And the reason for this is simple: For Colorado's regulatory regime to work, all marijuana production must be moved into the regulated and taxed system. If regulated entities - who pay licensing fees and must bear the costs of regulatory compliance - know that the facility growing marijuana next door to theirs is not doing the same, they will be tempted to cheat as well. Unlicensed marijuana production is not a regulatory issue, it is a criminal one - the Colorado Department of

34 1CCRR801.

35 Steven Nelson. Colorado Marijuana Arrests Continue Despite Legalization. US News. January 13, 2014. Http://www.usnews.com/news/articles/2014/01/13/colorado-marijuana-arrests-continue-despite-legalization ("Between January and September 2013, 1,194 people were charged in Colorado with possession of less than 2 ounces of marijuana, a misdemeanor. During the same period a year earlier, 6,422 people were charged with petty possession, meaning charges for that offense declined by 81 percent".). 
Revenueis authorized only to investigate malfeasance by licensed entities. Those growing large amounts of marijuana outside of the licensed regime are violating state criminal provisions and are subject to arrest, prosecution, and imprisonment. Thus, it is important that law enforcement officials continue to enforce the state's remaining criminal provisions against those who remain in violation of state law. And it is clear that this law enforcement activity is continuing even long after legalization has gone into place. For example, in March of 2015 Denver police and federal officials made a number of arrests as part of Operation Golden Gopher, a sophisticated smuggling operation that involved "tens of thousands of pounds" of marijuana, marijuana infused oils, and marijuana trim being transported from Colorado to Minnesota for sale in that state ${ }^{36}$.

\section{Taxation}

Like other states, Colorado taxes its regulated marijuana market; after all one of the promises made to voters in the campaign for Amendment 64 was the generation of increased revenue from taxing the sales in what had previously been a completely illicit economy. But it became evident early in the regulatory process that a policy of maximal tax rates would work at cross-purposes with the state's other regulatory goals. For example, a punitive sin-tax on marijuana would keep the prices in the regulated market artificially high, allowing a black market to thrive and giving licensed entities incentives to avoid the tax.

But deciding that tax rates should be set at a level that would maximize revenues without empowering the black market was only the first step. A number of questions remained. For example, at what level should marijuana be taxed? At the level of production, wholesaling, or retailing? Furthermore, what should be the metric for taxation? Should tax be based on weight (pounds of marijuana produced), cost (wholesale or retail price), or intoxicating effect (based on the amount of THC, the active ingredient in marijuana, produced)? Each method has its plusses and minuses - for example, a tax at the level of production makes diversion out of state to avoid tax more difficult ${ }^{37}$, but is more likely to be marked up to consumers than is a consumer sales tax. A tax on price is relatively easy to calculate, but is subject to deception on the part of the taxpayers. ${ }^{38}$

36 Press release of Attorney General Cynthia Coffman, March 26, 2015, available at: http://www.coloradoattorneygeneral.gov/press/news/2015/03/26/thirty_two_person_\%E2\%80\%9Clegal\%E2\%80\%9D_marijuana_drug_trafficking_conspiracy_dismantled.

37 See, Rand Report. At. 87 ("Other things being equal, it is also advisable to assess tax before leakage can occur. That criterion suggests collection early in the supply chain".).

38 See, Pat Oglesby. Bungling Bundling? Taxing Marijuana in Washington State. Huffington Post. August 3 , 2015.Http://www.huffingtonpost.com/pat-oglesby/bungling-bundling-axing-m_b_7918092.html:

Washington has a 37-percent tax on retail sales of marijuana (cannabis). If an ounce of cannabis costs $\$ 200$ before tax, tax adds $\$ 74$, to make $\$ 274$ total. So sellers developed a scheme: "Free pot with purcha- 
In the end, the legislature eventually settled upon a two-tier tax. Marijuana would be taxed at the wholesale leve $\left.\right|^{39}$ at an excise rate of $15 \%$. The legislature also imposed a special sales tax of $10 \%$ on the sale from retailers to consumers ${ }^{40}$. These taxes are on top of state and local sales taxes and any additional taxes that a locality wishes to impose on marijuana sales. Taken together, these taxes constitute an effective tax rate of around $29 \%$ in a city like Denver ${ }^{41}$. This is higher than the effective tax rate on marijuana than that paid on beer and wine, but significantly less than that paid on tobacco products $^{42}$.

\section{Results}

While there is still broad disagreement in the United States about the appropriate means of cannabis regulation, Colorado's regulatory regime has largely been seen as a success ${ }^{43}$. Despite dire predictions and a few very tragic headlines ${ }^{44}$, the transition from prohibition to a legal, regulated market has been a relatively smooth one in the state ${ }^{45}$. Recreational marijuana businesses opened on schedule on January 1, 2014 and robust regulations were in place to govern their con-

se of pipe!" The pot and the pipe are "bundled" into one price. So the customer buys a pipe for $\$ 35$, and gets an eighth of an ounce of pot -- "for free". The pipe is tax-free. (It's not cannabis -- duh.) And the price of the pot is zero. Thirty-seven percent of zero is zero. 37-percent tax avoided!

39 Originally, the decision to tax the wholesale price was something of a strange one. In Colorado's original recreational marijuana regulations, marijuana companies were required to be vertically integrated; only $30 \%$ of marijuana could be bought from a wholesaler rather than produced by the retailer. As a result, "the bulk of marijuana sales in Colorado have no wholesaler even in the picture. These are direct grower-toconsumer sales. No dollars change hands until the consumer comes in. So there is no wholesale price to measure 15 percent of". Pat Oglesby, Marijuana Tax Measurement: Dollars, Grams, THC, Huffington Post, http://www.huffingtonpost.com/pat-oglesby/marijuana-tax-measurement_b_5324705.html.

40 Joseph Henchman, Taxing Marijuana: The Washington and Colorado Experience, Tax Foundation, available at http://taxfoundation.org/article/taxing-marijuana-washington-and-colorado-experience ("Colorado's marijuana tax is structured as a 15 percent excise tax on the "average market rate" of wholesale marijuana, plus a 10 percent state tax on retail marijuana sales, plus the state sales tax of 2.9 percent, plus local sales taxes, plus local marijuana taxes such as a 3.5 percent tax in Denver".). Note that this was changed to a weight-based tax thereafter.

41 Id. ("When these taxes are added up, in Denver for example, a $\$ 30$ eighth of pot (1/8 oz.) will have about $\$ 8.59$ in taxes tacked onto it, or about a 29 percent overall tax rate".).

42 Id.; Ritchie King, How Much Tax Coloradans Will Actually Have to Pay on Their Marijuana, available at: http://qz.com/83411/how-much-tax-coloradans-will-actually-have-to-pay-on-their-marijuana/. Calculating actual tax rates requires a fair number of assumptions. For example, in Colorado, wine, beer and spirits are taxed by volume while marijuana is taxed by price.

43 The biggest roadblock to legalization came from public officials and private individuals suing Colorado seeking to enjoin the regulation of marijuana in the state. See, e.g., Sam Kamin, Can you fight Marijuana Law with RICO Suits? Jurist.orghttp://jurist.org/forum/2015/04/sam-kamin-marijuana-rico.php (April 6, 2015) ("Colorado has been the subject of multiple lawsuits in recent months, all of them challenging the state's first-in-the-nation tax and regulatory system for adult-use marijuana".)

44 See, e.g., Brandon Rittman, Denver Deaths Put Focus on Marijuana Edibles, USA Today (April 14, 2014) (describing a student falling to his death after eating a marijuana-infused cookie and a husband shooting his wife after consuming a marijuana edible).

45 As State Senator Pat Steadman put it in a press report a year into the experiment with marijuana sales: “Everyone keeps calling this 'Colorado's experiment with marijuana legalization,' but so far everything seems to be working better than planned. ... Right now we're still rolling things out, but it just seems to be 
duct. Prices were originally quite high in the recreational market; the novelty of the event increased demand and supply was suppressed as many participants in the medical market chose to delay entry to the recreational market. But the price has since fallen, taking much of the profit out of the black market ${ }^{46}$. While the original recreational marijuana regulations did not anticipate every contingency and had to be revised and updated as the market evolved, regulators were able to respond quickly to changing conditions on the ground, creating new rules to cover edible safety and labeling, home cultivation, and public consumption ${ }^{47}$. Both property and violent crime were down in Denver in 2014 compared with the year before ${ }^{48}$; Colorado's tourism numbers set records in $2014 .{ }^{49}$

From a revenue perspective, the results are slightly more sobering. It was widely reported that Colorado failed to meet its revenue targets during the first year of recreational sales, and this is almost certainly correct ${ }^{50}$. Total sales of marijuana amounted to just over $\$ 700$ million in 2014 which was split nearly evenly between recreational and medical sales ${ }^{51}$. These sales generated total tax revenue for the state of $\$ 63$ million ${ }^{52}$. In addition, the Department of Revenue collected almost $\$ 13$ million in licensing fees and fines; in sum, the state collected $\$ 76$ million in its first year of regulated sales. While this might seem like a lot of money, bear in mind that the total budget requested by Governor Hickenlooperfor fiscal year 2014-15 was \$24.1 billion. Marijuana tax revenue for all of 2014 thus consti-

rolling out smoother than anyone expected". http://www.thecannabist.co/2015/02/12/colorado-marijuanasales-2014-700-million/27565/

46 Nicholas Colas. Marijuana Store Survey and Industry Outlook Q2 2015, available at: http://www.convergex.com/the-share/marijuana-store-survey-and-industry-outlook-q2-2015 ("Since last June, the average price of an 1/8th ounce of recreational cannabis has dropped from $\$ 50-\$ 70$ to $\$ 30-\$ 45$ currently; an ounce now sells for between $\$ 250$ and $\$ 300$ on average compared to $\$ 300-\$ 400$ last year".).

47 See, e.g., Ricardo Baca. New Rules In Effect for Colorado Edibles. The Cannabis. February 1, available at: http://www.thecannabist.co/2015/01/29/colorado-marijuana-edibles-fire-sale-regulations-feb-1/28775/ (January 29, 2015); Jon Murray, Denver City Council Approves 36-Plant Limit for Collective Pot Grows, Denver Post http://www.denverpost.com/news/ci_27772099/denver-city-council-approves-36-plant-limitcollective (March 23, 2015).

48 Crime in the City and County of Denver Based on UCR Standards, available at: http://www.denvergov.org/ Portals/720/documents/statistics/2014/UCR_Citywide_Reported\%20_Offenses_2014.pdf.

49 Jason Blevins. Colorado Tourism Numbers Set Record in 2014. Denver Post. June 23, 2015.Http://www. denverpost.com/business/ci_28368011/2014-record-colorado-tourism.

50 See, e.g.. Kristen Wyatt. Colorado Pulls in \$76M in Marijuana Taxes and Business Fees for 2014. The Cannabist. February 10, 2015.Http://www.thecannabist.co/2015/02/10/colorado-pot-tax-44-million-recreational-taxes-2014/29510/ ("Colorado's total haul from marijuana for 2014 was about $\$ 76$ million. That includes fees on the industry, plus pre-existing sales taxes on medical marijuana products. The $\$ 44$ million represents only new taxes on recreational pot - a 10 percent special sales tax and a 15 percent excise tax on wholesale marijuana transfers. Those new taxes were initially forecast to bring in about $\$ 70 \mathrm{mi}-$ llion".).

51 Ricardo Baca. Chart: Colorado Marijuana Sales Hit $\$ 700$ Million for 2014. The Cannabist. February 12, 2015 (reporting $\$ 385.9$ million in sales of medical marijuana and $\$ 313.2$ million for recreational marijuana).

52 Data from: https://www.colorado.gov/pacific/revenue/colorado-marijuana-tax-data, chart available from author. I added up all taxes and fees collected by the state (line 17 of the chart). 15\% of the special sales tax on recreational marijuana is returned to counties; I did not deduct this amount, reporting instead the total amount collected by the state. 
tutes just $0.3 \%$ of the total budget. The governor's marijuana coordinator Andrew Freedman said at the time that while marijuana legalization had paid for itself, "there's been too much emphasis on money. It's not something that you do to fill budget shortfalls"53.

The principal reason for this shortfall was the (relatively) slow rollout of recreational stores in early 2014 . One of the primary reasons that medical marijuana licensees chose not to convert from medical to retail was concern about the implementation of the untested recreational regulations. But it was clear during the first 6 months of 2014 that there were strong incentives keeping marijuana customers in the medical, rather than recreational market. There are at least three factors pushing regular users to keep their medical card and continue to purchase marijuana in the medical system: Medical patients can purchase larger amounts of the drug (two ounces per purchase versus just one for recreational patients); those under 21 are excluded from the recreational market but can nonetheless buy in the medical market if they have a red card; medical marijuana is exempt from the state's tax system.

At first, this last point was a crucial one. Regular users of marijuana were unsurprisingly price-sensitive; they were used to paying lower, largely untaxed, medical prices and balked at the originally much higher price being charged at recreational stores. New, curious users, by contrast were willing to pay the full recreational price. The high demand for recreational marijuana and the low supply led to a high price spread between medical and commercial marijuana, and as a result medical sales remained strong in the first half of 2014 .

As more producers came online, however, the price dropped and the recreational sales (and revenue) have accelerated. For example, the revenue data for 2015 shows a pronounced improvement. In just the first 5 months of 2015, revenue is already approximately $60 \%$ of the total for all of 2014 . Perhaps even more important, the bulk of marijuana being sold in Colorado in 2015 is being sold in the more heavily taxed recreational market; in 2014 slightly more medical marijuana than recreational marijuana was sold. What is more, it is important to remember that these numbers measure only direct revenue to the state. They do not take into account ancillary benefits to the state such as jobs created in the marijuana industry, the development of ancillary businesses to service the marijuana industry, and increased tourism to the state.

53 Wilson Dizard. Advocates Hail Colorado Legal Pot As Success. Al Jazeera America. January 6, 2015. Http://america.aljazeera.com/articles/2015/1/6/pot-colorado.html. 


\section{California and the Colombia Example}

In many ways, Colorado is not the perfect analogy to the situation faced by postconflict Colombia. Colorado is not a state with a history of drug production and export; until 2010 when medical marijuana regulations went into effect, marijuana production in the state was virtually non-existent. The marijuana production that does exist in Colorado has been heavily regulated and tightly controlled from nearly the start, with severe penalties for any producer caught shipping marijuana out of state, selling to minors, trafficking other drugs, etc. In this regard, California is probably a closer analogy to the situation in which Colombia finds itself. California has been an exporter of marijuana to the rest of the country for decades. Although production for export is illegal in California, rural farmers in the northern part of the state have been engaging in that conduct with impunity for decades.

The so-called Emerald Triangle in Northern California - named for neighboring counties Humboldt, Mendocino, and Trinity counties - is home to a billion dollar illegal marijuana industry. While some of this production is nominally tied to California's weakly regulated medical market, much of it is patently illegal, grown for shipment out of state or to California's own black market. This illegal production receives at least tacit support from some local authorities; marijuana production sometimes goes back for generations and is part of the culture on the north coast of California. Thus it might seem ironic that all three of these counties voted against Proposition 19 in 2010 which would have legalized marijuana for adult users in the state. Yet the reason for their opposition is simple; currently those growing marijuana illegally in the Emerald Triangle have a near monopoly on the production of marijuana in the state and can charge their customers accordingly. Legalization would hurt their business.

The question of what to do with these legacy producers looms as California considers a legalization initiative in 2016. As we have seen from our discussion of Colorado, to be effective, a regulated market needs to be the exclusive source of marijuana in a given jurisdiction. If a black market is allowed to thrive alongside an expensive, complex, and taxed model, it will have a necessary advantage over those paying regulatory and licensing fees and costs as well as state tax. In such a regime the state will lose revenue, licensed entities will have an incentive to cheat, and the state will risk becoming a target of federal enforcement.

It was for this reason that the Blue Ribbon Commission working with California Lieutenant Governor Gavin Newsom to consider legalization issues saw unregulated rural growing of marijuana as one of the most pressing regulatory concerns facing the state: 
Illegal cultivation, especially trespass grows on public and private land, will remain a problem that deserves attention even after legalization. A portion of the cannabis that is cultivated in California will be sold for consumption outside California, in violation of federal law. These types of illegal grows and large operations aimed at out-of-state sales would need to be enforcement priorities for the state, both to promote public safety and to comply with federal guidelines. ${ }^{54}$

The options available for regulators will be limited, however. Under legalization, illegal cultivation could be allowed to continue as it does currently. As we have seen this result is likely untenable, despite its appeal to a core group of marijuana advocates that legalization forces would rather not alienate. Another approach suggested by the Blue Ribbon Commission was a policy of focusing on the worst of the worst of outdoor producers: "One approach would be to concentrate law enforcement resources on those operations 1) being carried out on public lands or trespassing private lands, 2) engaged in environmentally destructive practices, or 3) also engaged in other violent and serious crime" 55 . This approach would curtail illegal growing (and its worst impacts), but would allow "law-abiding" illegal growers to remain in place. A more aggressive approach would be to give illegal grows an opportunity to join the legal market (and presumably to prosecute them if they continue to produce if they do not submit to regulation). This inclusive approach would be an olive branch to the illegal producers, but would probably not bring in all illegal producers and might raise the ire of the local community when those opting out of the market were shut down. At the far extreme is an approach that excludes anyone who has been part of the illegal market from the legal, regulated one. This approach would certainly show the federal government that California was serious about ferreting the criminal element out of its regulated market, but would lead to ugly conflicts with entrenched local interests.

As I hope is obvious by now, each of these approaches would have significant downsides. A permissive approach to illegal cultivation cripples the legal market, while a punitive approach looks like the failed prohibition that reform advocates are attempting to replace ${ }^{56}$. This difficult question of how to deal with legacy producers remains one of the most difficult questions facing California as 2016 approaches. While I will not pretend to be an expert on drug production and its politics in Colombia, it seems to me that there is an analogy to be drawn between the

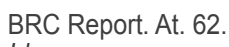

See, e.g., BRC Report. At. 62 ("Historically, the enforcement strategies aimed at illegal cultivation and sales have had a limited impact on either the supply or the demand for marijuana. Taking a more heavyhanded approach to enforcement poses challenges even after legalization: it may simply drive the illicit cannabis industry deeper into public lands and into more remote areas".). 
choices facing California and the post-conflict situation in your country. If legalization of marijuana or other drugs is to proceed here, a difficult decision will need to be made regarding whether and how to bring within the regulated market those who were previous participants in the illicit market.

\section{Conclusion}

In this short article, I have hoped to share what I have learned from Colorado's now nearly three-year-old experiment with marijuana legalization and regulation. As someone who has both written about and participated in the process of regulating marijuana in the United States, I both appreciate the potential of legalization and recognize its limits. As I hope I have explained, there are good reasons to consider legalizing marijuana, but it is not obvious to me that a sensible regulatory regime would be a great boon for Colombia's economy. The costs of running an effective regulatory regime are high and taxes must be kept moderate in order to prevent the continued flourishing of the black market. Furthermore, it would raise difficult questions regarding what to do with those who have been in the business of violating Colombian law and whether they can be successfully integrated into a regulated and taxed regime. This is meant not to discourage Colombia from reconsidering its participation in the war on drugs, but to help inform the nation as it moves into its post-conflict phase. 